\title{
Парадуоденальний (groove) панкреатит: сучасний погляд на діагностику та хірургічне лікування
}

\author{
А. І. Хомяк
}

Національний інститут хірургії та трансплантології імені О. О. Шалімова НАМН України, м. Київ

\section{Paraduodenal (groove) pancreatitis: contemporary approach to the diagnosis and surgical treatment}

\author{
A. Khomiak \\ Shalimov National Institute of Surgery and Transplantology, Kyiv
}

Незважаючи на стрімкий розвиток медицини, захворювання підшлункової залози (ПЗ) вивчені недостатньо, а їх діагностика та лікування складні. Хронічний панкреатит (ХП) - прогресуюче запальне захворювання ПЗ, що характеризується незворотними морфологічними змінами, втратою паренхіми залози і заміщенням іiі фіброзною тканиною, внаслідок чого орган втрачає ендокринну та екзокринну функціі [1]. Парадуоденальний панкреатит (ПДП) - окрема форма ХП, що характеризується хронічним запаленням, фіброзними змінами та рубцюванням парадуоденальної зони [2, 3]. Анатомічними орієнтирами парадуоденальної зони є: латерально - низхідна частина дванадцятипалої кишки (ДПК), медіально - головка ПЗ і загальна жовчна протока (ЗЖП), попереду верхня частина ДПК або антральний відділ шлунка, позаду - горизонтальна частина ДПК або нижня порожниста вена. Протягом останніх років про дослідження ПдП досить часто повідомляється у фаховій літературі, та досі немає консенсусу щодо класифікації, діагностики та лікування даного захворювання.

Термінологія щодо ПДП довгий час залишалась невизначеною. Перші згадки про ПДП з'явилися у 1970-х роках. Даний патологічний процес визначали як кістозну дистрофію гетеротопічної ПЗ, кістозну трансформацію стінки ДПК, міоаденоматоз стінки ДПК, парадуоденальну кісту, гамартому ПЗ або гамартому брунерівських залоз, псевдопухлину, вживалися й інші менш поширені назви [4 - 7]. Втім, скоро стало зрозуміло, що всі ці терміни використовуються для позначення одного й того самого патологічного процесу.

3 патоморфологічної точки зору, терміни «кістозна дистрофія стінки ДПК» та «парадуоденальна/дуоденальна кіста» $€$ некоректними щодо ПДП. Значна частина пацієнтів з ПДП має кістозні зміни, але не всі випадки ПдП супроводжуються появою кіст. Термін «кістозна дистрофія гетеротопічної ПЗ» означає, що часточки ПЗ наявні у стінці ДПК (так звана гетеротопія ПЗ). Проте визначення «кістозна», як було зазначено вище, не завжди відображає сутність процесу, а панкреатичні часточки в нормі наявні в ділянці малого сосочка ДПК. Як правило, панкреатичні елементи при ПДП сполучені з ПЗ, що не дає підстав судити про справжню гетеротопію [7].

Назва «groove панкреатит» - одна з найбільш розповсюджених назв даного патологічного процесу[6, 7] виникла тому, що в запальний процес часто залучається анатомічна ділянка панкреатодуоденальної борозни (pancreaticoduodenal groove) між ПЗ, ДПК та ЗЖП. Проте насправді здебільшого патологічні зміни сконцентровані у стінці ДПК у ділянці ії малого сосочка. Більш того, запальний процес при даному захворюванні майже ніколи не обмежується ділянкою groove, поширюючись на ЗЖП, головку ПЗ [6 - 7]. Тому у 2004 p. N. Adsay i G. Zamboni запропонували об'єднати всі ці терміни в один - «парадуоденальний панкреатит». Термін «парадуоденальний» було вжито тому, що запальні зміни переважають у стінці ДПК та ділянці groove, але можуть поширюватись на ПЗ та ЗЖП. Хоча запальні зміни переважають у стінці ДПК та ділянці groove, термін «панкреатит» вживають тому, що патологічний процес містить ацинарні часточки та протоки панкреатичного типу з патоморфологічними особливостями, характерними для алкогольного ХП. На даний момент найбільш точним є таке визначення ПДП це форма ХП, що характеризується хронічним запаленням ПЗ, фіброзними змінами та рубцюванням низхідної частини ДПК та ділянки groove [7 - 9].

Клінічні прояви ПДП можуть значно відрізнятися. Пацієнти можуть мати скарги, характерні як для гостро- 
го, так і для хронічного панкреатиту. Нерідко ПДП проявляється як новоутворення періампулярної зони або дуоденальна непрохідність. Якщо захворювання має «гострий» перебіг, пацієнти скаржаться на сильний біль у животі, нудоту, блювання та уповільнене випорожнення шлунка. Пацієнти з симптоматикою «хронічного» перебігу захворювання скаржаться на наявність жовтяниці (внаслідок стенозування та формування стриктур дистального відділу позапечінкових жовчних проток), хронічну втрату маси тіла, загальну слабкість. Такі клінічні прояви характерні для новоутворень періампулярної зони та вказують на необхідність проведення ретельної диференціальної діагностики ПДП та пухлинних утворень [10 - 13].

У 1991 p. V. Becker та U. Mischke запропонували класифікувати groove панкреатит на три види: чистий groove панкреатит, сегментарний панкреатит головки ПЗ та ХП iз залученням ділянки groove [6]. Згідно з радіологічною класифікацією виділяють два види захворювання: чиста форма, яка характеризується локалізацією процесу в ділянці groove без ураження головки П3, і сегментарна форма, яка передбачає ураження ділянки groove та головки ПЗ з iї патологічними змінами (фіброз, утворення кіст) [14 17]. Обидві класифікації мають недоліки перш за все тому, що спираються на застарілі визначення ПДП, через те виникає сумнів щодо досконалого розуміння процесу авторами.

Радіологічну картину ПДП при мультиспіральній комп'ютерній томографії (МСКТ) описують по-різному в залежності від форм захворювання, згаданих вище. У пацієнтів з чистою формою радіологічні знахідки можуть варіюватися від слабо вираженого запалення жирової клітковини між ДПК та головкою ПЗ до запалення м'яких тканин з рідинними включеннями в панкреатодуодеальній борозні, які зазвичай мають листоподібну криволінійну форму півкола та найкраще візуалізуються на коронарних зрізах [13]. На мультифазній МСКТ ці м'які тканини найкраще контрастуються у відстрочену фазу, що пов'язано з їх фіброзними змінами. Нерідко спостерігають потовщення медіальної стінки ДПК (найкраща візуалізація в коронарній проекціi) та наявність маленьких кіст у потовщеній стінці кишки та ділянці groove [18].

У пацієнтів із сегментарною формою ПДП пухлиноподібно збільшена головка ПЗ часто перешкоджає гарній візуалізації панкреатодуоденальної борозни. Це надзвичайно ускладнює радіологічну діагностику цієї форми ПдП, а диференціювати іiі з пухлинами періампулярної зони на основі даних МСКТ майже неможливо [13].

Незалежно від форми ПДП ретроперитонеальних запальних змін, наявних при гострому інтерстиційному набряковому панкреатиті, зазвичай немає. Рідина в периренальному просторі візуалізується вкрай рідко, а дифузні запальні зміни зазвичай мінімально виражені. Для обох форм захворювання характерна погана візуалізація ЗЖП та звуження ії просвіту. У більшості пацієнтів звуження ЗЖП поступове, без нерівностей та загострень. Протока ПЗ також часто поступово звужується у напрямку до ії го- ловки. У разі довготривалого перебігу хвороби через звуження протоки ПЗ та порушення відтоку панкреатичного соку можуть розвиватися радіологічні зміни, характерні для класичного ХП. До них відносять появу кальцифікатів, розширення протоки в тілі та хвості ПЗ, а також їі зміни з формуванням дрібних псевдокіст («намиста») [18].

Картина ПДП на магнітно-резонансній томографіі (MPT) багато в чому відповідає картині ПдП на МСКТ. Контрастування листоподібних м'яких тканин у формі півкола в ділянці панкреатодуоденальної борозни підсилюється у віддаленій фазі через наявність фіброзу, але вони дещо гіпоінтенсивні на Т1-зважених зображеннях, a iнтенсивність їх контрастування на Т2-зважених зображеннях може відрізнятися в залежності від інтенсивності запалення. В гостру фазу запалення, коли наявні набряк та рідина, м'які тканини на Т2-зважених зображеннях є гіперінтенсивними, але з часом через збільшення вмісту фіброзного компонента вони стають гіпоінтенсивними [13 - 15].

У пацієнтів із сегментарною формою ПДП залучення у запальний процес паренхіми ПЗ добре візуалізується на МРТ як прогресивна втрата інтенсивності Т1-сигналу в головці ПЗ через атрофію та фіброз паренхіми. На медіальну стінку ДПК запальний процес поширюється при чистій та сегментарній формах ПДП. На МРТ це візуалізується як потовщення медіальної стінки ДПК і множинні Т2-гіперінтенсивні кісти у стінці ДПК та панкреатодуоденальній борозні [13-15].

Магнітно-резонансна холангіопанкреатографія (МРХПГ) дає змогу добре оцінити аномалії дистального відділу ЗЖП та протоки ПЗ, які часто мають вигляд стенозованих у ділянці ампули великого сосочка ДПК. Тубулярний стеноз ЗЖП та формування стриктур у ї̈ дистальному відділі можуть спричиняти збільшення жовчного міхура, що часто описують як бананоподібний жовчний міхур. Для визначення аномалій у ділянці панкреатодуоденальної борозни на МРХПГ можна користуватись методом вимірювання відстані між ампулою та просвітом ДПК, яка зазвичай збільшена через наявність м'яких тканин у ділянці панкреатодуоденальної борозни та потовщення стінки ДПК [13 - 15].

Візуалізація ПдП під час трансабдомінальної та ендоскопічної ультрасонографії (ЕУС) подібна, а його ультразвукова (УЗ) картина залежить від гостроти та тривалості перебігу захворювання. На ранній стадії захворювання, коли насамперед переважає запальний, а не фіброзний компонент, під час ЕУС візуалізується гіпоехогенне потовщення панкреатодуоденальної борозни та стінки ДПК. Крім зазначених знахідок, за наявності сегментарної форми захворювання можна візуалізувати гіпоехогенну гетерогенну головку ПЗ. У разі хронічного перебігу за наявності великої кількості фіброзного компонента гіпоехогенне потовщення панкреатодуоденальної борозни стає гіперехогенним. Якщо переважає фіброзний компонент, змінюються й УЗ-зображення головки ПЗ (при сегментарній формі) та потовщеної стінки ДПК, які також стають гіперехогенними $[13,19]$. 
ЕУС - один із найважливіших методів обстеження у диференціальній діагностиці ПДП. Під час ЕУС часто візуалізується звуження ЗЖП. Додаткова протока ПЗ, яку зазвичай легко візуалізувати під час ЕУС у пацієнтів без ПДП, стає майже непомітною [10]. Біопсію під контролем ЕУС вважають найбільш надійним тестом для підтвердження наявності злоякісного новоутворення. У загальній популяції діагностична цінність (чутливість) методу, за даними різних авторів, становить від 80 до 95\%. Проте за наявності супутнього ХП чутливість методу знижується до $50-75 \%[20-23]$.

Роль ендоскопічної ретроградної холангіопанкреатографії (ЕРХПГ) у діагностиці ПДП незначна. Єдина важлива знахідка під час ЕРХПГ - це звуження ЗЖП, яке майже неможливо диференціювати від ії стенозу за наявності пухлинних утворень періампулярної ділянки [10, 13].

Диференціальна діагностика ПДП з пухлинними утвореннями періампулярної ділянки залишається складним клінічним завданням. Певній категорії пацієнтів через неможливість виключити наявність пухлинних утворень виконують радикальні хірургічні втручання [11]. Серед таких пацієнтів найбільше тих, що мають злоякісні новоутворення, які походять з ділянки панкреатодуоденальної борозни або щільно прилягають до неї та не спричиняють класичної для аденокарциноми обструкції ЗЖП, iii обриву чи атрофії ПЗ при візуалізуючих методах обстеження. Проте на відміну від ПДП аденокарцинома ПЗ дистальніше місця обструкції, як правило, не викликає кістозних змін та набагато частіше інфільтрує органи заочеревинного простору, в тому числі спричиняючи інвазію судинних структур; накопичення контрасту на МСКТ або МРТ має більш плямистий та гетерогенний характер при ПДП на відміну від рівномірного та гіподенсивного при аденокарциномі ПЗ [13 - 15].

Лікування ПДП є невирішеною проблемою сучасної панкреатологіі.

Не існує консенсусу щодо оптимальної тактики лікування паціентів з ПДП. Усі наявні дані здебільшого отримані шляхом проведення окремих суперечливих ретроспективних досліджень з малою вибіркою [8 - 13].

Лікування ПДП має декілька напрямів: консервативна терапія та модифікація способу життя, ендоскопічні мініінвазивні методи та відкриті хірургічні втручання. Окремі автори пропонують застосовувати покрокову тактику лікування класичного ХП у хворих з ПДП. М. Arvanitakis та співавтори у 2014 р. опублікували результати дослідження, згідно з якими покрокова стратегія є ефективним та безпечним підходом до лікування такої категорії пацієнтів. Проте в даному дослідженні не порівнювали покроковий підхід з хірургічним лікуванням та не визначили конкретного алгоритму лікування захворювання. Тому потрібно більше якісних досліджень для визначення оптимальної стратегії лікування ПДП [11, 12, 17, 24 - 32].

Консервативне лікування ПДП багато в чому збігається 3 консервативною терапією класичного ХП та має симптоматичний характер. Для лікування больового синдро- му застосовують аналгетики відповідно до «сходинок знеболювання» ВООЗ. Показана модифікація способу життя з відмовою від паління та вживання алкоголю, пацієнтам призначається дієта. У деяких пацієнтів через стеноз ДПК повноцінне ентеральне харчування неможливе, такі пацієнти харчуються парентерально. Хороші результати застосування соматостатину та його пролонгованих аналогів у контролі больового синдрому також описані в літературі. Є повідомлення про застосування інгібіторів протонної помпи в комплексній терапії ПдП. У цілому консервативна терапія ПдП є малоефективною, а роль та місце препаратів певних груп, лікувальна тактика невивчені [11, 12, 17, 24 - 34].

Ендоскопічні методи, які мають свої переваги й недоліки, широко застосовують в лікуванні ПДП. Серед них папілосфінктеротомія, дилатація та стентування стриктур головної та додаткової проток ПЗ, стентування ЗЖП, ДПК за наявності їі стенозу, а також дренування панкреатичних псевдокіст. Найчастіше застосовують дренування панкреатичних псевдокіст, ефективне у паціентів із симптоматичними псевдокістами парадуоденальної ділянки, та ендоскопічне стентування додаткової протоки ПЗ через малий сосочок ДПК. У літературі наведені дані про значне покращення загального стану та зменшення болю після ендоскопічного стентування додаткової протоки ПЗ при ПДП. Проте ендоскопічна терапія має ряд недоліків, зокрема, це високі частота рецидивів та ризик ускладнень у разі порушення функції стентів. Також бракує даних, які б надійно свідчили про безпеку та ефективність таких методів у довгостроковій перспективі, оскільки навіть у короткостроковій перспективі успіх ендоскопічних методів лікування може варіювати від 37,5 до 80\%. Через це багато авторів вважають консервативні та ендоскопічні методи лікування проміжним етапом для стабілізації стану пацієнта та корекції функцій органів перед остаточним хірургічним лікуванням. Також ендоскопічні та консервативні підходи можуть бути остаточною стратегією лікування пацієнтів 3 найлегшими формами ПДП або пацієнтів, що мають протипоказання до відкритих хірургічних втручань через супутню патологію [1 1, 12, 17, 24, 26, 31 - 35].

Більшість авторів сходяться на думці, що показаннями до хірургічного лікування ПДП є невдалі спроби консервативних та ендоскопічних методів лікування, виникнення ускладнень та неможливість виключення злоякісного процесу. Для хірургічного лікування ПДП запропоновані та використовуються дуоденозберігаючі резекції ПЗ, резекція ДПК із збереженням ПЗ, панкреатодуоденектомія (із збереженням і без збереження пілорусу) та резекція головки ПЗ із сегментарною резекцією ДПК (операція Nakao). Хоча багато авторів для хірургічного лікування ПДП застосовують здебільшого панкреатодуоденектомію, така радикальна тактика може бути невиправданою для лікування доброякісного захворювання. Панкреатодуоденектомія є ефективним втручанням для лікування ПДП, що виражається у зменшенні больового синдрому та відновленні нормальної маси тіла у післяопераційному періоді, Більше того, за 
даними літератури у разі застосування панкреатодуоденектомії із збереженням і без збереження пілорусу ризик виникнення ускладнень вищий, ніж у разі застосування органозберігаючих операцій [9 - 12, 17, 24 - 28, 36 - 40].

За аналогією 3 хірургічним лікуванням класичного ХП 3 переважним ураженням головки ПЗ у пацієнтів з ПДП виконують дуоденумзберігаючі резекції П3, зокрема операції Фрея та Бегера, Бернську методику тощо. Застосування таких оперативних втручань передбачає резекцію запальних тканин головки ПЗ, які спричиняють больовий синдром та ускладнення (компресію навколишніх органів і судин), та формування панкреатоєюноанастомоза для налагодження відтоку панкреатичного соку. Дуоденумзберігаючі резекції ПЗ можуть бути більш доцільними для лікування хворих з ПДП, зважаючи на їх ефективність, яка відповідає панкреатодуоденектомії, та меншу частоту ускладнень. Проте на даний момент немає переконливих даних, які свідчили б про перевагу однієї з методик [10, 38 - 41].

Операція Nakao вперше була описана для лікування інтрапанкреатичної муцинозної неоплазії ПЗ та передбачає виконання резекції 5 - 7 см другої порції ДПК у ділянці виходу ії малого та великого сосочків та збереження першої, третьої та невеликої частини другої порцій ДПК. Реконструктивний етап полягає у виконанні панкреатогастростомії та формуванні дуоденодуоденального анастомоза. Описано застосування резекції ДПК із збереженням ПЗ для лікування ПДП, що обумовлено патоморфологічними даними про концентрацією патологічних змін при ПДП у малому сосочку та стінці ДПК. Роль та місце таких процедур у лікуванні ПДП наразі невідома, а отже, має бути вивчена в майбутніх дослідженнях [39].

Таким чином, у сучасній хірургічній панкреатології не існує єдиної класифікації ПДП, багато авторів досі вживають некоректні терміни щодо даного захворювання. Не визначено чітких показань та немає єдиної думки щодо вибору методу хірургічного лікування. Наведене свідчить про надзвичайну актуальність проблеми діагностики та хірургічного лікування ПДП. Уточнення алгоритмів діагностики, розроблення нових та удосконалення існуючих класифікацій захворювання, визначення оптимальних термінів застосування оперативних та мініінвазивних методів та їх місця у хірургічному лікуванні ПДП дадуть змогу покращити результати лікування даної когорти пацієнтів.

\section{Підтвердження}

Інформація про фінансування. Дана наукова робота виконується в рамках комплексної НДР.

Інформація про конфлікт інтересів. Потенційного або явного конфлікту інтересів, пов'язаного з цим рукописом, немає.

\section{References}

1. Whitcomb DC, Frulloni L, Garg P, Greer JB, Schneider A, Yadav D, et al. Chronic pancreatitis: An international draft consensus proposal for a new mechanistic definition. Pancreatology. 2016;16(2):218-24 doi: 10.1016/j.pan.2016.02.001.
2. Potet F, Duclert N. Cystic dystrophy on aberrant pancreas of the duodenal wall. Arch Fr Mal App Dig. 1970;59(4):223-38. PMID: 5419209.

3. Muraki T, Kim GE, Reid MD, Mittal P, Bedolla G, Memis B, et al. Paraduodenal Pancreatitis: Imaging and Pathologic Correlation of 47 Cases Elucidates Distinct Subtypes and the Factors Involved in its Etiopathogenesis. Am J Surg Pathol 2017;41(10):1347-63. doi: 10.1097/ PAS.0000000000000919.

4. Stolte M, Zink W, Schaffner O. Duodenal wall cysts and diseases of the pancreas. Leber Magen Darm. 1983;13(4):140-9. PMID: 6676617.

5. Stolte M, Weiss W, Volkholz H, Rösch W. A special form of segmental pancreatitis: "groove pancreatitis". Hepatogastroenterology. 1982;29(5):198- 208. PMID: 7173808.

6. Becker V, Mischke U: Groove pancreatitis. Int J Pancreatol. 1991;10(34):173-82. doi: 10.1007/BF02924155.

7. Adsay NV, Zamboni G. Paraduodenal pancreatitis: a clinico-pathologically distinct entity unifying "cystic dystrophy of heterotopic pancreas", "para-duodenal wall cyst", and "groove pancreatitis". Semin Diagn Pathol. 2004; 21(4):247-54. doi: 10.1053/j.semdp.2005.07.005

8. Muraki T, Kim GE, Reid MD, Mittal P, Bedolla G, Memis B, et al. Paraduodenal Pancreatitis: Imaging and Pathologic Correlation of 47 Cases Elucidates Distinct Subtypes and the Factors Involved in its Etiopathogenesis. Am J Surg Pathol. 2017;41(10):1347-63. doi: 10.1097/ PAS.0000000000000919.

9. Casetti L, Bassi C, Salvia R, Butturini G, Graziani R, Falconi M, et al. "Paraduodenal" pancreatitis: results of surgery on 58 consecutives patients from a single institution. World J Surg. 2009;33(12):2664-9. doi: 10.1007/s00268-009-0238-5.

10. Tezuka K, Makino TY, Hirai I, Kimura W. Groove pancreatitis. Dig Surg. 2010;27(2):149-52. doi: 10.1159/000289099

11. Manzelli A, Petrou A, Lazzaro A, Brennan N, Soonawalla Z, Friend P. Groove pancreatitis: a mini-series report and review of the literature. JOP. 2011;12(3):230-3. PMID: 21546697.

12. Kim JD, Han YS, Choi DL. Characteristic clinical and pathologic features for preoperative diagnosed groove pancreatitis. J Korean Surg Soc. 2011;80(5):342-7. doi: 10.4174/jkss.2011.80.5.342.

13. Raman SP, Salaria SN, Hruban RH, Fishman EK. Groove pancreatitis: spectrum of imaging findings and radiology-pathology correlation. AJR Am J Roentgenol. 2013;201(1): W29-39. doi: 10.2214/AJR.12.9956.

14. Blasbalg R, Baroni RH, Costa DN, Machado MC. MRI features of groove pancreatitis. AJR. 2007;189(1):73-80. doi: 10.2214/AJR.06.1244.

15. Castell-Monsalve FJ, Sousa-Martin JM, Carranza-Carranza A. Groove pancreatitis: MRI and pathologic findings. Abdom Imaging. 2008;33(3):342-8. doi: 10.1007/s00261-007-9245-x.

16. Wook KS, Suk K, Woo LJ, Kyung LN, Won KC, Seon YM, et al. Evaluation of unusual causes of pancreatitis: role of crosssectional imaging. Eur J Radiol. 2009;71(2):296-312. doi: 10.1016/j.ejrad.2008.04.006.

17. Rebours V, Lévy P, Vullierme MP, Couvelard A, O'Toole D, Aubert A, et al. Clinical and morphological features of duodenal cystic dystrophy in heterotopic pancreas. Am J Gastroenterol. 2007;102(4):871-9. doi: 10.1111/j.1572-0241.2007.01091.x.

18. Itoh S, Yamakawa K, Shimamoto K, Endo T, Ishigaki T. CT findings in groove pancreatitis: correlation with histopathological findings. J Comput Assist Tomogr. 1994;18(6):911-5. doi: 10.1097/00004728199411000-00011.

19. Wronski M, Karkocha D, Slodkowski M, Cebulski W, Krasnodebski I. Sonographic findings in groove pancreatitis. J Ultrasound Med. 2011; 30(1):111-5. doi: 10.7863/jum.2011.30.1.111.

20. Raut CP, Grau AM, Staerkel GA, Kaw M, Tamm EP, Wolff RA, et al. Diagnostic accuracy of endoscopic ultrasound-guided fineneedle aspiration in patients with presumed pancreatic cancer. J Gastrointest Surg. 2003;7(1):118-26. doi: 10.1016/S1091-255X(02)00150-6.

21. Eloubeidi MA, Chen VK, Eltoum IA, Jhala D, Chhieng DC, Jhala N et al. Endoscopic ultrasound-guided fine needle aspiration biopsy of patients with suspected pancreatic cancer: Diagnostic accuracy and acute 
and 30-day complications. Am J Gastroenterol. 2003;98(12):266. doi: 10.1111/j.1572-0241.2003.08666.x

22. Varadarajulu S, Tamhane A and Eloubeidi MA. Yield of EUS-guided FNA of pancreatic masses in the presence or the absence of chronic pancreatitis. Gastrointest Endosc. 2005;62(5):728-36. doi: 10.1016/j. gie.2005.06.051.

23. Will U, Mueller A, Topalidis T, Meyer F. Value of endoscopic ultrasonography-guided fine needle aspiration (FNA) in the diagnosis of neoplastic tumor (-like) pancreatic lesions in daily clinical practice. Ultraschall Med. 2010;31(2):169-74. doi: 10.1055/s-0028-1109491.

24. Triantopoulou C, Dervenis C, Giannakou N, Papailiou J, Prassopoulos P. Groove pancreatitis: A diagnostic Challenge. Eur Radiol. 2009;19(7):1736-43. doi: 10.1007/s00330-009-1332-7.

25. Meesiri S. Groove pancreatitis: Report of one case in Thailand. J Med Assoc Thai. 2009;92(11):1554-9. PMID: 19938751.

26. Sunnapwar A, Prasad SR, Menias CO, Alampady KS, Rashmi K, Abhijit R. Nonalcoholic, nonbiliary pancreatitis: Cross-sectional Imaging spectrum. AJR Am J Roentgenol. 2010;195(1)67-75. doi: 10.2214/ AJR.09.4048.

27. Arvanitakis M, Rigaux J, Toussaint E, Eisendrath P, Bali MA, Matos C, et al. Endotherapy for paraduodenal pancreatitis: A large retrospective case series. Endoscopy. 2014;46(7):580-7. doi: 10.1055/s-0034-1365719.

28. Balakrishnan V, Chatni S, Radhakrishnan L, Narayanan VA, Nair P. Groove pancreatitis: A case report and review of literature. JOP. 2007;8(5):592-7. PMID: 17873465.

29. Sanada Y, Yoshida K, Itoh H, Kunita S, Kazuto J, Hideo M. Groove pancreatitis associated with true pancreatic cyst. J Hepatobiliary Pancreat Surg. 2007;14(4):401- 9. doi: 10.1007/s00534-006-1180-7.

30. Ito R, Shiba H, Okamoto T, Fujioka S, Gocho T, Yanaga K. Groove pancreatitis with several cystic lesions around pancreatic head treated conservatively: Report of a case. Case Rep Gastroenterol. 2008;2(3):4059. doi: $10.1159 / 000164310$.

31. Levenick JM, Sutton JE, Smith KD, Gordon SR, Suriawinata A, Gardner TB. Pancreaticoduodenectomy for the treatment of groove pancreatitis. Dig Dis Sci. 2012;57(7):1954-8. doi: 10.1007/s10620-012-2214-4.

32. Pezzilli R, Santini D, Calculli L, Casadei R, Morselli-Labate AM, Imbrogno A, et al. Cystic dystrophy of the duodenal wall is not always associated with chronic pancreatitis. World J Gastroenterol. 2011;17(39):4349-64. doi: 10.3748/wjg.v17.i39.4349.
33. Patriti A, Castellani D, Partenzi A, Carlani M, Casciola L. Pancreatic adenocarcinoma in paraduodenal pancreatitis: A note of caution for conservative tretaments. Updates Surg. 2012;64(4):307-9. doi: 10.1007/ s13304-011-0106-3.

34. Laugier R, Grandval P. Does paraduodenal pancreatitis systematically need surgery? Endoscopy. 2014;46(7):588-90. doi: 10.1055/s-00341377268.

35. Isayama H, Kawabe T, Komatsu Y, Sasahira N, Toda N, Tada M, et al. Successful treatment for groove pancreatitis by endoscopic drainage via the minor papilla. Gastrointest Endosc. 2005;61(1):175-8. doi: $10.1159 / 000485849$.

36. Varma V, Gandhi V, Bheerappa N, Sastry RA. Groove pancreatitis mimicking pancreatic malignancy. Indian J Gastroenterol. 2008;27(2):86. PMID: 18695314.

37. Viñolo-Ubiña C, Morales Ruiz J, Heredia Carrasco C, Ruiz-Cabello-Jiménez M, Villegas-Herrera MT, Garrote-Lara D. Groove pancreatitis with duodenal stenosis. Rev Esp Enferm Dig 2010(2);102:59-60. doi: 10.4321/s1130-01082010000100012.

38. German V, Ekmektozoglou KA, Kyriakos N, Patouras P, Kikilas A. Pancreatitis of the gastroduodenal groove: A case report. Case Report Med. 2010;2010:329587. doi:10.1155/2010/329587.

39. Nakao A. Pancreatic head resection with segmental duodenectomy and preservation of the gastroduodenal artery. Hep Gastr. 1998;45(20):5335. PMID: 9638444.

40. Frey C, Mayer K. Comparison of local resection of the head of the pancreas combined with longitudinal pancreaticojejunostomy (Frey procedure) and duodenum-preserving resection of the pancreatic head (Beger procedure). World J Surg. 2003;27(11):1217-30. doi: 10.1007/ s00268-003-7241-z.

41. Usenko O, Kopchak V, Khomiak I, Khomiak A, Malik A: Results of surgical treatment of paraduodenal (groove) pancreatitis. Klin Khir. 2018;85(11):5-8. doi: 10.26779/2522-1396.2018.11.05.

Надійшла 19.06.19 